International Journal of Applied Linguistics \& English Literature

ISSN 2200-3592 (Print), ISSN 2200-3452 (Online)

Vol. 1 No. 4; September 2012

\title{
A Brief Review of Theoretical Underpinnings, Definitions and Typical Configurations of Collaborative Writing
}

\author{
Seyed Yasin Yazdi Amirkhiz (Corresponding Author) \\ Department of Language and Humanities Education, Faculty of Educational Studies \\ Universiti Putra Malaysia, 43400 UPM Serdang, Selangor Malaysia \\ Mobile: +60173059737 Email: Nasser_yazdi@yahoo.com \\ Kamariah Abu Bakar \\ Institute for Mathematical Research, Universiti Putra Malaysia \\ Roselan Baki \\ Department of Language and Humanities Education, \\ Faculty of Educational Studies, Universiti Putra Malaysia \\ Arshad Abd Samad \\ Department of Language and Humanities Education, \\ Faculty of Educational Studies, Universiti Putra Malaysia \\ Karim Hajhashemi \\ School of Education, \\ James Cook University, Australia
}

Received: 29-06- 2012

Accepted: 28-07- 2012

Published: 01-09- 2012

doi:10.7575/ijalel.v.1n.4p.197

URL: http://dx.doi.org/10.7575/ijalel.v.1n.4p.197

\begin{abstract}
The aim of this paper is to review the underlying concepts, theoretical background, the existing definitions, various forms of collaborative writing normally used in educational settings as well as some sample studies carried out in different contexts. The article begins by providing an epistemological dichotomy of the existing educational paradigms and discusses the positioning of collaborative learning in relation to the dichotomy (transmissional vs. transformative). It then considers how collaborative writing is theoretically backed up by the ideas of Bakhtin (1981), Halliday (1978), and Vygotsky (1978). The review also compares the salient definitions of collaborative writing and critically contrasts various configurations of collaborative writing with regard to the findings of research studies. The article concludes by recommending a few directions for the future research.
\end{abstract}

Keywords: theoretical background, definitions, forms of collaborative writing

\section{Introduction}

Zuengler and Miller (2006) acknowledge the existence of conflicting ideologies and different epistemological stances (how knowledge is acquired) in the realm of second language acquisition (SLA). From the epistemological perspective, there have been two major related views which have affected our educational outlooks: transmissional and transformative. The transmissional view, which dominated mainstream education most of twentieth century, is based on the notions "of knowledge as a commodity to be transmitted to learners, and of language as a 'conduit' by which this process of transmission occurred" (Gibbons, 2006, pp. 15-16). This approach considers knowledge to be external to the learner and acquired through a variety of activities such as 
practicing routines and procedures developed by others. Antithesis of the transmissional epistemological orientation is transformative outlook which is staunchly advocated by proponents of constructivism. Unlike the proponents of the transmissional nature of knowledge creation, the constructivists tend to believe in the transformative nature of learning and knowledge construction. Based on the transformative outlook, learners themselves are at the focus of attention and they co-construct meaning through their interpretive interactions in their social environments.

\section{Collaborative Writing: Theoretical Underpinnings}

The theoretical basis for collaborative writing or writing groups is the notion of collaborative learning which is, in turn, rooted in the social constructivist view of learning and knowledge. Researchers seeing writing as a socio-contextual phenomenon have drawn upon the theoretical frameworks set forth by Bakhtin (1981), Halliday (1978), and Vygotsky (1978). The three theoreticians' common intellectual denominator is seeing language and learning as a process of making meaning and as a social activity.

Based on Vygotsky's (1978) general genetic low of cultural development, the transformation of lower forms of thinking (elementary perception, involuntary attention, and natural memory) into higher forms of thinking (comprehension of language, logical reasoning, decision-making, planning, problem solving, etc) takes place as a result of mediation, language being one of the most important tools of the mediation process. Basically, the core of Vygotsky's attention is on "the developmental affordances provided by language" (Lantolf \& Thorne, 2006, p. 207). A similar characterization of language has been made by Halliday (1978) as well. Like Vygotsky, Halliday (1978) believes that "meaning potentials" are actualized with reference to all the socio-semiotic factors involved in the communication process. Bakhtin believed in the potentials of dialogic interactions. Bakhtin (1986) sees "the unique speech experience of each individual [as being] shaped and developed in continuous and constant interaction with others' individual utterances" (p. 89). For him, language learning is, in fact, an act of appropriation of others' words and utterances.

Assuming such an essential role for social interaction (in the form of conversational activities) is shared by social constructivists, in general, and by those believing in dialogic view of writing and writing pedagogy, in particular. The advocates of dialogic view of writing believe that social conversation has a pivotal role in the planning, production, and revision of texts (Bruffee, 1995). According to this view, oral discourse is essentially the arsenal of ideas as it provides us with the ideas we write about. Hence, the rhetorical modes we use to frame those ideas and even the words and expressions that find their way into our written texts are ultimately appropriated from the conversations that we may happen to have with others.

\section{Collaborative Writing: Definitions}

A review of pertinent literature reveals that there exist varying conceptions and definitions of collaborative writing. Saunders (1989) makes a distinction between "co-writing" and other forms of collaborative activities such as "co-publishing" and "co-responding". Ede and Lunsford (1990) used the term "group writing" instead of collaborative writing and defined it as any group writing activity performed in collaboration with other persons. It should be mentioned that in their study, planning and revising were done collaboratively, but the drafting was not necessarily carried out collaboratively. Louth, McAllister and McAllister (1993) defined it as "group members interact during the writing process and the group is responsible for the final product" (p. 217). They held the view that group writing should be distinguished from interactive writing and both should be tested as techniques of collaborative writing. Their study showed that the quality of the collaboratively-written essays was similar to that of independently-written ones, but students who worked through collaboration overall produced better post-tests and they seemed to be more satisfied with their achievements than the independent writers. Bosley (as cited in Ede \& Lunsford, 1990, p.15) defined collaborative writing as, "two or more people working together to produce one written document in a situation in which a group takes responsibility for having produced the document." More recently, Storch (2011) defined it as "the joint production or the coauthoring of a text by two or more writers" (p. 275). What seems to make her definition distinct from the previous definitions is her accentuation of "joint ownership" and the partners' collaboration throughout the entire writing process. She further commented that "the defining trait of collaborative writing is the joint ownership of the document produced. Thus collaborative writing is distinguished from the group-planning or peer feedback activities that are often manifest as part of the process approach to writing instruction (p.275). In fact, what makes her definition distinct from the previous definitions is her accentuation of "joint ownership" and the partners' collaboration throughout the entire writing process. Putting all the definitions together, one may conclude that 
the quality of the text. In three-stage collaborative writing, the three stages of writing process are integrated and collaboration continues during the entire writing process. Given the abundance of peer revision studies (one-stage collaborative writing) in the literature as well as the recent increasing attention of the researchers to the three-stage collaborative writing, a number of relevant research studies are reviewed below.

\subsubsection{Peer Revision}

Peer revision is a form of collaborative writing in which "students share and comment on drafts of each other's papers" (Hirvela, 2004, p. 160). According to Hyland and Hyland (2006), peer revision became outstanding in writing instruction as a result of emergence and development of learner-centered approaches, which gave further significance to learner's voice and role. O'Brien (2004) and Storch (2005) are of the opinion that peer review (revision) has been the most common and frequently practiced way of working in peer groups. O'Brien (2004) further asserts that most of the research into collaborative writing has addressed the revision stage of the writing process.

Liu and Hansen (2002) support the use of peer response (peer revision) with regard to learning potentials afforded by the collaborative nature of the practice. They argue that peer revision is anchored in and supported by the four theoretical stances: process writing, collaborative writing, Vygotskian perspective and interactionist theories of L2 acquisition. Hirvela (1999) supports the use of peer response as in peer feedback the learners capitalize on the dialogic and collaborative resources and complete tasks that they could not do on their own. By the same token, Hyland and Hyland (2006) emphasize the role of peer feedback in occurrence of interactional modifications which in turn could make acquisition possible by making input available and comprehensible for learners. They also argue that peer feedback can provide learners with some opportunities for practice, for testing hypotheses about language use against peers' responses, as well as for revising and writing in response to peer feedback.

Results from L2 research suggest that peer revision can play a positive role in writing instruction: (a) peer revision may positively affect the quality of the text (Hedgcock and Lefkowitz, 1992); (b) it can encourage collaborative dialogue in which two-way feedback is established (Grabe \& Kaplan, 1996; Rollinson, 2005); (d) it could be cognitively beneficial to the students through articulation of explanations between the peers during peer revision (Wooley, 2007); (e) engaging in peer revision can also enhance students' communicative power by encouraging students to express and negotiate their ideas (Mendonca \& Johnson, 1994); (f) peer response activities could also boost students' confidence and reduce their apprehension by allowing them to see peers' strengths and weaknesses in writing (Leki, 1990). (f) peer revision makes it possible for the learners to be exposed to a variety of writing styles (Berg, 1999; Mendonca \& Johnson, 1994).

Some Studies have particularly addressed the effect of peer revision on text quality. For instance, Hedgcock and Lefkowitz (1992) found that the total scores for the essays of those EFL university students who were involved in peer- revision sessions were higher than the total scores of the students who received only written feedback from teachers. Whereas in peer-revised essays the content, vocabulary and organization were better, in teacher-directed revised papers the grammar and mechanics fronts had higher scores. Villamil and Guerrero (1998) ascribed the longer second drafts produced by 54 ESL students to their being involved in peer revision sessions. Berg (1999) added the variable of training to the peer revision. He compared the quality of the written texts of ESL students who had had training in how to participate in peer response groups with the texts of those who had had no such training. The study found that the trained group made higher-quality revisions, more meaning changes and fewer surface changes than the untrained group.

However, despite the sample benefits cited above and many other advantages noted by other researchers, the idea of peer revision has substantially been criticized by a number of scholars. Rollinson (2005) stated that:

Although both research and practice have generally supported the use of peer feedback activities in ESL and L2 writing classes, many teachers (and most students) are less than convinced of its usefulness in their own particular situation (p. 23).

Topping (2001) points out that the implementation of the practice could be frustrating because the existing collaborative writing models lack structured guidelines for students to follow. Liu and Hansen (2002) claim that uncertainty concerning peers' comments, lack of learner investment, superficial comments due to time limitations, and inappropriate interactions in commenting on peers' drafts are the four recurring reservations concerning the use of peer response activities in the teaching of L2 composition. Also, many research studies (Fury, 2004; Mangelsdorf, 1992; Mendonca \& Johnson, 1994; Mooney, 2004) have found that learners only 
selectively approach the comments that are mentioned by their peers. According to these researchers, the learners in their studies tended to depend more on their own or their teachers' knowledge rather than the feedback provided by their peers. For example, Manglesdorf (1992) who conducted a study on Asian learners attributes the tendency of the learners to look down on the peer feedback to the effect of teacher-centered culture.

One of the most accentuated drawbacks of peer reviews recorded in the literature is that since students review each other's finished written product (text), the focus is on the product of writing rather than the process of writing. In L2 context some scholars (Lockhart \& Ng, 1995; Nelson \& Carson, 1998; Villamil \& Guerrero, 1996) have shown that when L2 learners are asked to do peer revision, they tend to focus on word and at best sentence level. Leki (1990) states that students sometimes focus too heavily on "surface concerns" (p. 9), or editing, neglecting larger revising issues. Hirvela (1999) points out that when assistance is postponed to the last stage (i.e.,revision stage) the writers are left to their own devices when making important decisions about their text.

A number of scholars (e.g., Daiute, 1986; Storch, 2011; Wells, Chang and Maher, 1990) argue that students should collaborate throughout the writing process, and collaboration should not be confined to the final stage of writing, but rather the students should have joint responsibility throughout the stages: brainstorming, composing and revising. This sense of joint responsibility may indeed promote a sense of co-ownership. Weissberg (2006) is of the opinion that "engaging students in dialogue about their writings can allow them more opportunity, not only to clarify and defend their meanings, but also build a greater sense of ownership over their texts" (p.74). Hence, this sense of joint responsibility and "positive interdependence" (Jacobs, 2004) among the collaborators encourages them to contribute to decision making on all aspects of writing: content, structure, and language. Ede and Lunsford (1990) refers to this as a singular text/plural authors approach.

\subsubsection{Collaboration during the Entire Writing Process}

Some studies also have been carried out to show the effect of collaborative writing over the entire writing process on students' text quality. Storch (1999) compared individual and pair performance of his students on a range of grammar-focused exercises, including a short composition. The results of the study indicated that the collaboratively-completed exercises were generally more accurate than the tasks when the same participants completed the tasks individually. In a cross-sectional study, Kuiken and Vedder (2002) investigated the role of group interaction in L2 writing. Their study aimed to test the hypothesis that "text quality in L2 is positively affected by collaborative dialogue: when learners are given the opportunity to reconstruct together a text, which has been read to them by the teacher, their joint product will be better than an individual reconstruction" ( $p$. 169). The study was conducted among 40 Dutch, English and Italian as second language students with an intermediate level of proficiency. The focus of the study was on syntactic and lexical quality of text produced by the learners when they interacted with each other. Moreover, they looked into "the kind of grammatical and lexical strategies which L2 learners use while being engaged in a collaborative writing activity" (170). The results of the study showed that there was a strong relationship between interaction among the group members on metalinguistic awareness and the quality of the text they produced.

Storch (2005) investigated the writing produced by two groups of students with fairly advanced level of English proficiency. The participants were 23 ESL students who were completing degree courses at a large university in Australia. They were given the chance to work on a writing task individually or in pairs. Eighteen students chose to work in pairs, and five opted to work individually. The study showed that the students working in pairs produced shorter but more syntactically complex and grammatically accurate texts than the texts produced by students of the other group who had done the task individually. Furthermore, the jointly-produced texts had a better structure and clearer focus, which was interpreted as an indication of the students' competence enhancement in task fulfillment. However, the differences were not deemed statistically significant due to the small-scale nature of the study.

In a similar study, Storch and Wigglesworth (2007) made a comparison between the writings of pairs and individuals working on the same writing tasks. The data were collected from 72 postgraduate students with an advanced level of English proficiency at a university in Australia. Of 72 participants, 24 performed the two writing tasks individually and 48 (24 pairs) completed the same two writing tasks in pairs. The results obtained for this study was similar to the results of Storch's study in 2005: pairs produced texts with greater accuracy than individual writers.

Wigglesworth and Storch (2009) conducted a large-scale experimental study among advanced ESL learners. They compared texts produced by 48 pairs with texts produced by 48 learners working individually. The 
International Journal of Applied Linguistics \& English Literature

ISSN 2200-3592 (Print), ISSN 2200-3452 (Online)

Vol. 1 No. 4; September 2012

investigators found that there were no statistically significant differences between the jointly-written and individually-produced texts in terms of fluency and complexity. However, the texts produced by the pairs were more accurate than the texts produced by the individuals.

More recently. Shehadeh (2011) investigated the effectiveness of collaborative writing and students' perceptions of collaborative writing in two intact English classes, consisting of 18 students (experimental group) and 20 students (control group). The results of the study showed that collaborative writing had an overall significant effect on students' L2 writing. The effect was specifically significant for content, organization, and vocabulary, but not for grammar or mechanics.

\section{Concluding Remarks}

Overall, the above reviews show that a majority of research studies investigating the effects of collaborative writing have been mainly focused on peer response activities, and the small number of the studies (Kuiken \& Vedder, 2002; Storch, 1999, 2005; Storch, \& Wigglesworth, 2007; Wigglesworth \& Storch, 2009) on the collaborative writing (entire writing process) that exist in the literature have mostly ventured a comparison between the quality of jointly-produced texts vis-à-vis individually-produced texts. Thus, the eventual effect of collaborative writing on the quality of individual writing has yet to be investigated. Furthermore, the effect of collaborative writing on the quality of individual L2 writing among EFL vs. ESL learners, male vs. female L2 learners (i.e., gender effect), and the role that different genre types (e.g., descriptive, argumentative) could play in the collaborative performance of the collaborators are some of the possible avenues for the future research, to name a few.

\section{References}

Bakhtin, M. (1981). The Dialogic Imagination: Four Essays. Austin: University of Texas Press.

Bakhtin, M. (1986). Speech Genres and Other Late Essays. Austin: University of Texas Press.

Berg, E. C. (1999). The effects of trained peer response on ESL students' revision types and writing quality. Journal of Second Language Writing, 8(3), 215-241.

Blanton, L. L. (1992). Talking students into writing: Using oral fluency to develop literacy. TESOL Journal, 1(4), 23-26.

Bond, M. H. E. (1996). The handbook of Chinese psychology: Oxford University Press.

Bruffee, K. A. (1995). Peer tutoring and the "conversation of mankind.". Landmark Essays: Writing Centers, 87-98.

Daiute, C. (1986). Do 1 and 1 Make 2? Written Communication, 3(3), 382.

Davies, N. F., \& Omberg, M. (1987). Peer group teaching and the composition class. System, 15(3), 313-323.

Ede, L., \& Lunsford, A. (1990). Singular texts/plural authors. Carbondale: Southern Illinois University Press.

Ewert, D. E. (2009). L2 writing conferences: Investigating teacher talk. Journal of Second Language Writing, 18(4), 251-269.

Ferris, D. (2003). Response to student writing: Implications for second language students: Lawrence Erlbaum.

Freedman, S. (1987). Response to Student Writing: Teaching and learning. NCTE Research Monograph Series.

Urbana, IL: National Council of Teachers of English.

Freedman, S., \& Sperling, M. (1983). Teacher Student Interaction in the Writing Conference: Response and Teaching.

Fury, F. (2004). English 1, Spring 2004. Retrieved on July, 4, 2009.

Gibbons, P. (2006). Bridging discourses in the ESL classroom: Students, teachers and researchers: Continuum Intl Pub Group.

Goldstein, L. M., \& Conrad, S. M. (1990). Student input and negotiation of meaning in ESL writing conferences. TESOL Quarterly, 443-460. 
International Journal of Applied Linguistics \& English Literature

ISSN 2200-3592 (Print), ISSN 2200-3452 (Online)

Vol. 1 No. 4; September 2012

Grabe, W., \& Kaplan, R. B. (1996). Theory and practice of writing: An applied linguistic perspective: Longman New York.

Halliday, M. A. K. (1978). Language as Social Semiotic: The social interpretation of language and meaning. London: Arnold.

Hedgcock, J. and N. Lefkowitz (1992). "Collaborative oral/aural revision in foreign language writing instruction." Journal of Second Language Writing 1(3): 255-276.

Hirvela, A. (1999). Collaborative writing instruction and communities of readers and writers. TESOL Journal, $8(2), 7-12$

Hirvela, A. (2004). Connecting reading and writing in second language writing instruction, University of Michigan Press.

Hyland, K., \& Hyland, F. (2006). Feedback in second language writing: Contexts and issues, Cambridge University Press.

Jacobs, G. M. (2004). Cooperative learning: theory, principles and techniques. JF New Paradigm Education.

Kuiken, F., \& Vedder, I. (2002). Collaborative writing in L2: The effect of group interaction on text quality. In Rijlaarsdam, Gert (Series Ed.), Ransdell, Sarah \& Marie-Laure Barbier (Vol. Eds), Studies in Writing, 11, 169-188.

Lantolf, J. P., \& Thorne, S. L. (2006). Sociocultural theory and the genesis of second language development: Oxford University Press.

Leki, I. (1990). Coaching from the margins: Issues in written response. Second language writing: Research insights for the classroom, 57-68.

Liu, J., \& Hansen, J. G. (2002). Peer response in second language writing classrooms: University of Michigan Press.

Lockhart, C., \& Ng, P. (1995). Analyzing talk in ESL peer response groups: Stances, functions, and content. Language Learning, 45(4), 605-651.

Louth, R., McAllister, C., \& McAllister, H. A. (1993). The effects of collaborative writing techniques on freshman writing and attitudes. The Journal of Experimental Education, 61(3), 215-224.

Mangelsdorf, K. (1992). Peer reviews in the ESL composition classroom. ELT Journal, 46(3), 274-284.

Mendonca, C. O., \& Johnson, K. E. (1994). Peer review negotiations: Revision activities in ESL writing instruction. TESOL Quarterly, 745-769.

Mooney, C. (2004). Beware 'sound science.' It's doublespeak for trouble. Washington Post, 29.

Nelson, G. L., \& Carson, J. G. (1998). ESL students' perceptions of effectiveness in peer response groups. Journal of Second Language Writing, 7(2), 113-131.

Norton, B., \& Toohey, K. (2001). Changing perspectives on good language learners. TESOL Quarterly, 35(2), 307-322.

O'Brien, T. (2004). Writing in a foreign language: Teaching and learning. Language Teaching, 37(01), 1-28.

Powers, J. K. (1993). Rethinking Writing Center Conferencing Strategies for the ESL Writer. Writing Center Journal, 13(2), 39-47.

Rollinson, P. (2005). Using peer feedback in the ESL writing class. ELT Journal, 59(1), 23-30.

Saunders, W. M. (1989). Collaborative writing tasks and peer interaction. International Journal of Educational Research, 13(1), 101-112.

Shehadeh, A. (2011). Effects and student perceptions of collaborative writing in L2. Journal of Second Language Writing, 20(4), 286-305.

Storch, N. (1999). Are two heads better than one? Pair work and grammatical accuracy. System, 27(3), 363-374. 
International Journal of Applied Linguistics \& English Literature

ISSN 2200-3592 (Print), ISSN 2200-3452 (Online)

Vol. 1 No. 4; September 2012

Storch, N. (2005). Collaborative writing: Product, process, and students' reflections. Journal of Second Language Writing, 14(3), 153-173.

Storch, N. (2011). Collaborative Writing in L2 Contexts: Processes, Outcomes, and Future Directions. Annual Review of Applied Linguistics, 31(1), 275-288.

Storch, N., \& Wigglesworth, G. (2007). Writing tasks: Comparing individual and collaborative writing. In M. P. G. Mayo (Ed.), Investigating tasks in formal language learning (pp. 157-177). London, UK: Multilingual Matters.

Topping, K. (2001). Paired collaborative writing.: www.scre.ac.uk/rie/n167/n167topping.html.

Ulichny, P., \& Watson-Gegeo, K. A. (1989). Interactions and authority: The dominant interpretive framework in writing conferences. Discourse Processes, 12(3), 309-328.

Villamil, O. S., \& Guerrero, M. (1998). Assessing the impact of peer revision on L2 writing. Applied Linguistics, 19(4), 491-514.

Vygotsky, L. (1978). Mind in society: The development of higher psychological processes: Harvard University

Press.

Weissberg, R. (2006). Scaffolded feedback: Tutorial conversations with advanced L2 writers. Feedback in Second Language Writing. Contexts and Issues.

Wells, G., Chang, G. L. M., \& Maher, A. (1990). Creating classroom communities of literate thinkers.

Wigglesworth, G., \& Storch, N. (2009). Pair versus individual writing: Effects on fluency, complexity and accuracy. Language Testing, 26(3), 445.

Williams, J. (2002). Undergraduate Second Language Writers in the Writing Center. Journal of Basic Writing, 21(2), 73-91.

Williams, J. (2004). Tutoring and revision: Second language writers in the writing center. Journal of Second Language Writing, 13(3), 173-201.

Wong, I. (1988). Teacher-student talk in technical writing conference. Written Communication, 5, 444-460.

Wooley, R. S. (2007). The effects of web-based peer review on student writing. Kent State University.

Zamel, V. (1985). Responding to student writing. TESOL Quarterly, 79-101.

Zuengler, J., \& Miller, E. R. (2006). Cognitive and sociocultural perspectives: Two parallel SLA worlds? TESOL

Quarterly, 40(1), 35-58. 